Nippon Suisan Gakkaishi $\quad$ 83(1), 83 (2017)

\title{
ミニシンポジウム記録 水産資源の持続的利用と認証制度
}

\section{3. 水産養殖管理協議会（ASC） と日本の養殖業}

\author{
前川 聡 \\ WWF ジャパン 自然保護室
}

3. Aquaculture Stewardship Council (ASC) and aquaculture in Japan

SATOSHI MAEKAWA

World Wide Fund for Nature, Nature Conservation Division, Minato, Tokyo 105-0014, Japan

ASC は 2010 年にオランダに設立された，自然環境と 社会に対し責任ある養殖事業を普及拡大するための基準 と消費者ラベルの管理と認証制度の普及を行う非営利組 織です。2012 年にベトナムのティラピア養殖場が認証 を取得したのを皮切りに現在ではその数は 200（2016 年 3 月当時）を超えます。日本では 2014 年に大手量販 店で販売が開始, 2016 年には宮城県の牡蠣養殖場が国 内初の認証取得を果たしました。ASC 認証はFAO と ISEALのガイドラインに準拠した水産養殖に関する唯 一の認証制度で，基隼策定から認証過程まで高い透明性 と客観性を持っています。対象とする魚種は現在 8 基 準 12 魚種ですが，今後海藻も含め多くの魚種に拡大す る予定です。ASC 基準は基本的に 7 つ原則から構成 されますが，法令遵守や自然環境に関する基準だけでは なく, 労働条件や地域社会との連携にかかる基準が含ま れていることも，ASC 基準の大きな特徵となっていま す。

ASC 認証を取得するため生産者は厳しい環境基準を クリアする必要があります。ASC 認証への取り組み は, 漁場環境を適切に管理保全するインセンティブとな ります。また，国際的に認知度のある認証制度を活用し
たブランド化や販売チャンネルの開拓のほか, 認証製品 への一定の需要による取引価格の安定化などが期待され ています。いっぽう対象魚種の少なさや監査費用の問題 など, 解決すべき課題もいくつかありますが, 改善の方 向に向かっています。ここ $1 \sim 2$ 年で国内でも認証監查 を受託できる認証機関の数が増え, また取り扱い企業数 も増えてきました。

日本初の ASC 認証を取得した宮城県漁協志津川支所 戸倉出張所のカキ養殖は, 2011 年の東日本大震災でほ ぼすべての養殖施設を損失しましたが, その後の復旧過 程でそれ以前の過密養殖による生産効率の低下を改善 し, 海の環境に合わせ良質の牡蠣作りを目指すため, 養 殖密度を大幅に削減しました。結果として生産にかかる コストや作業時間を削減しただけではなく, カキの生産 性を向上させることに成功しました。また将来予想され る同様の災害に対しても被害額を削減することにつなが ります。今後, 組合員と一致団結し生産体制を維持する のか，そして ASC 認証を活かしたブランド・製品づく りを進め, 定期的に発生する監査費用を確保するのかが 課題となっています。

いっぽう国内の魚類養殖生産量の 6 割を占めるぶり 類についても, 生産者の ASC に対する期待が高まって います。ブリの監査体制は今年にも整うとされています が，ブリ養殖を基盤とする国内の大手漁協では, 自ら高 品質のモノづくりをけん引してきた自負に加え, 既存の サプライチェーンからの要望や輸出による販路拡大, 天 然や他産地との差別化を視野に準備を進めています。ぶ り類の場合, 最大の難関は飭料効率で, アンチョベータ なぞの天然魚由来の魚粉魚油の使用率を下げる生産技術 を確立しなければなりません。そのため, 生産者だけで はなく飼料メーカーなど幅広い連携が求められます。 